\title{
Folket, eliten og \\ demokratiet i Tunesien
}

\section{Rikke Hostrup Haugbølle}

\section{Officielt fremstår Tunesien som homogent, men skal der skabes en farbar vej mod en egentlig demokratiudvikling, må fokus flyttes til den diversitet, der præger befolkningen}

Man møder ham ikke før eller siden, men med det samme: Tunesiens præsident, Zine al-Abedine Ben Ali. I lufthavnens ankomsthal holder han på store billboards hånden på hjertet i en varm og venlig gestus. Rundt om i landet hænger plakaterne fra et besøg i en landsby. Præsidenten støtter to gamle damer i traditionelle klædedragter, mens de sammen går ned gennem landsbyen, hvor de yngre kvinder og endeløse rækker af glade børn klapper og synger.

Det harmoniske billeder fra landsbyen støtter den forestilling, der ofte gøres omkring Tunesien som et homogent og harmonisk land. 98 pct. af befolkningen er sunni-muslimer, og der er ingen etniske grupperinger af politisk betydning. Islamisternes voldelige kamp for mere åbenhed i det politiske system blev der sat en stopper for i slutningen af 1980'erne, og de er siden da ikke blevet tilladt at operere i landet. Der er afholdt flere valg, hvor en opposition tilsyneladende også er repræsenteret, og der er igangsat økonomiske reformer.

National enhed, homogenitet og etableringen af en suveræn stat sættes ofte som forudsætninger for at en demokratiproces kan etableres og forventes at få et positivt forløb. I arabiske lande som Irak og Libanon er de faktorer således centrale for udviklingen af demokrati. I Tunesiens tilfælde kan det imidlertid konstateres, at trods religiøs og etnisk homogenitet og en stærk stat siden selvstændigheden, synes demokratiprocessen at være gået i stå.

Opfattelsen af den tunesiske befolkning som homogen og synet på Tunesien som et harmonisk land og 
som et eksempel til efterfølgelse for andre arabiske lande er netop det, der gør blind over for forklaringen på den stækkede demokratiproces. Forudsætningen tegnet af homogeniteten er det, der som udgangspunkt sender demokratiprocessen ind på et forkert spor og i en retning, hvor den ikke kan bære frugt.

Fire forhold viser sig som centrale for en forståelse af præmisserne i Tunesien og dermed for igangsættelsen af en demokratiproces, der vil følge en positiv, frugtbar udvikling.

Det første forhold angår skabelsen af det nationale fællesskab som den eneste officielle identitet. Denne homogenitet har udmøntet sig i en politisk uniformitet. Det næste forhold knytter sig til de magtstrukturer, der gør sig gældende på lokalt niveau. Det viser sig nemlig, at trods fokus fra styrets side på national enhed, er det fortsat stammer og familier, der danner rammen om den enkeltes følelse af tilhørsforhold, og som er regulerende for den enkelte tunesers hverdag.

Et tredje forhold har vist sin relevans i kølvandet på de økonomiske reformer, der har været gennemført siden slutningen af 1980 'erne. I stedet for højere grad af liberalisering har reformerne igen gjort det traditionelle patron-klient forhold relevant. Det fjerde og sidste forhold, der er afgørende i demokratiprocessen, er strukturen i den elite, der reelt har den politiske magt og indflydelse i landet.

\section{Den tunesiske familie}

Præsidenten som en alfaderlig figur og det nære, følelsesbetonede og familiære forhold mellem præsidenten og folket, som gør sig gældende i dag, blev udviklet og skabt af Habib Bourguiba i de første år efter Tunesiens selvstændighed i 1956. En række ledende mænd fra selvstændighedsbevægelsen Neo-Destour blev udnævnt til ministre i den nye regering, men Bourguiba sørgede for at pacificere konkurrenter og blev hurtigt den eneste ledende figur, en landsfader.

Han udviklede en ideologi, som omfattede alle aspekter af det tunesiske samfund. Ideologien betegnes bourguibisme og var inspireret og influeret af russisk kommunisme, Nassers socialisme i Egypten og Kemal Atatürks sekularistiske ideer for Tyrkiet.

Bourguiba tilpassede ideologierne til de aktuelle tunesiske forhold og til det formål, som ideologien skulle tjene i en specifik tunesisk kontekst. Bourguiba havde nemlig alene fokus på Tunesien og interesserede sig kun for etableringen af nationalstaten Tunesien. Målet var at skabe en nation, der stod stærkt både socialt, økonomisk og politisk, så man en gang for alle kunne gøre sig fri fra udenlandsk indblanding.

Bourguibas stærkeste kort til opbygningen af en nation var $i$ hans øjne befolkningen. Denne skulle mobiliseres i én fælles kamp for opbyggelsen af nationen. Til mobilise- 
ringen af folket skabte Bourguiba én fælles identitet som 'tuneser'. Det var første gang, identiteten som tuneser blev italesat og blev aktiveret.

Frem til protektoratet var landet formelt en del af Det Osmanniske Rige, men befolkningen betragtede sig som stammer og familier, som havde tilhørsforhold til en bestemt by eller region. Det var familien som ramme for den enkeltes identitet og tilhørsforhold, som Bourguiba genanvendte og førte op på et nationalt plan, idet han skabte begrebet 'den tunesiske familie'.

I lighed med tidligere tider skulle solidaritet, fællesskabsfølelse og forpligtelse knyttes til familien. Men familie-begrebet skulle ikke længere forstås som den enkelte kernefamilie. 'Familien' skulle nu forstås som hele nationen, Tunesien og alle tunesere. Dermed blev alle øvrige identiteter og tilhørsforhold som stamme, familie, region og etnisk oprindelse udvisket og trængt i baggrunden. 'Den tunesiske familie' skulle udgøre hele fundamentet for nationen.

I en af sine hyppige taler fra 1962 siger Bourguiba således at "Bevidstheden om den solidaritet og det broderskab, der forbinder medlemmerne af den tunesiske familie [..] udgør cementen i den fælles nation”. Den velkendte loyalitetsfølelse blev overført til en national sammenhæng. "Vi er alle sammen sammen”, sagde Bourguiba og talte om "vores muligheder". Bourguiba videreudviklede den enorme popularitet, han havde i befolkningen, til en rolle hvor han selv blev fader - landsfader - for denne nyskabte tunesiske familie.

Med tiden udviklede det sig til at blive Bourguibas nation, hans folk, hans politiske system - eller som han selv udtrykte det "Hvilket system? Jeg er systemet".

\section{Enhed og uniformitet}

Efter det ublodige kup i 1987 overtog Ben Ali rollen som nationens fader. Besøget i landsbyen foreviget på plakaten og de daglige klip på tv fra præsidentens besøg hos den tunesiske familie viser, at 'vi' fortsat alle er i samme båd. Hermed styrkes styrets fremstilling af en nation, hvor alle er lige i ét fællesskab.

Mens Bourguiba, idealistisk set, havde opbygningen af nationen som målet med den tunesiske familie, er Ben Alis mål fastholdelse af magten. For så længe der kun er én familie og ét fællesskab, er der kun brug for én leder, et overhoved, nemlig Ben Ali selv. I en politisk kontekst er familien repræsenteret i regeringspartiet, og også her kan det siges at ligge implicit i tanken om ét fællesskab, at der kun er brug for ét parti, idet dette menes at udtrykke og varetage den tunesiske families interesser.

I Tunesien kan nationalt fællesskab og enhed dermed siges at være blevet synonym for og ensbetydende 
med politisk uniformitet. Mens der i andre sammenhænge stræbes efter og arbejdes for at skabe en stærk stat og en samlet nation som forudsætning og garant for demokratiprocessen, er det i Tunesien netop styrets betoning af enhed og uniformitet, der står i vejen for politisk pluralisme.

Den stærke og ensidige betoning af og fokus på den nationale identitet og enhed undergraver snarere end fremmer igangsættelsen af udviklingen mod et demokratisk politisk miljø.

\section{Stammen og familien}

Trods styrets stærke og ensidige fokus på den nationale identitet gennem en periode på mere end 50 år er det ikke lykkedes for denne fællesskabsramme at trænge igennem og fordrive andre følelser af tilhørsforhold. I den tunesiske befolkning gør en stor bevidsthed om regionale forskelle og den enkeltes tilhørsforhold til bestemte familier og stammer sig nemlig gældende.

Den første skelnen i befolkningen sker mellem nord og syd. I den nordlige og særligt den nordøstlige del omkring hovedstaden Tunis og de store kystbyer Hammamet og Sousse har den franske kultur som følge af protektorattiden sat sit tydelige præg på livsformerne.

I syd derimod føler mange en stærk samhørighed med den øvrige arabiske befolkning, og man er sig meget bevidst om sit arabiske ophav.
Mange kan føre deres slægtslinjer tilbage til de første indvandrede stammer fra Den Arabiske Halvø. Bevidstheden om slægtslinjer, som ofte skabes på baggrund af mundtligt overleverede fortællinger, er i dag med til at skabe en anden selvforståelse end den, der knytter sig til den nationale identitet.

Denne bevidsthed har konsekvenser for de sociale og magtmæssige forhold, der gør sig gældende i en lokal kontekst. Byen Douz i det sydlige Tunesien kan tjene som eksempel på den sondering i en slægtsbestemt opdeling, som gør sig gæeldende i hele landet. Douz er en i tunesisk sammenhæng større by med 30.000 indbyggere. Geografisk set udgør byen én samlet enhed uden forstæder og med $10 \mathrm{~km}$ til de nærmeste nabobyer.

Imidlertid betragtes byen af dens befolkning som værende opdelt i to dele. Den ene domineres af den stamme (på tunesisk qabila), der hedder Marazig, mens den anden udgøres af qabilaen Aouina. Marazig-befolkningen betragter sig som efterkommere af byens forfader, mens Aouina-befolkningen er efterkommere af en af forfaderens følgesvende.

I en Marazig-selvforståelse er Aouina-befolkningen derfor ikke 'rigtige' Maraziger og dermed ikke 'rigtige' borgere i byen. Derfor har de stadig i en Marazig-selvforståelse ikke legitim ret til magtfulde stillinger i fx byens administration. Såle- 
des har borgmesterposten længe været Marazig-domineret, og fremtrædende Marazig-folk mener, at når den nuværende Aouina-borgmester går af, er det Marazigernes tur til at få posten igen.

Skellene mellem forskellige befolkningsgrupper gør sig imidlertid ikke kun gældende mellem de forskellige qba'il (flertal af qabila) på øverste niveau. Inden for Marazigqabila'en skelner befolkningen mellem flere mindre stammer, kaldet 'arsh, som geografisk er delt mellem tre kvarterer i den vestlige del af Douz. Også mellem disse 'urush (flertal af 'arsh) er der et indbyrdes hierarki. Igen er nogle 'arsh direkte efterkommere efter forfaderen mens andre er efterkommere af folk, der nød dennes beskyttelse.

Disse sidste efterkommere synes fortsat i dag at rangere under forfaderens direkte efterkommere i et forhold, der måske bedst kan karakteriseres som et patron-klient forhold med de direkte efterkommere som patronerne. Trods dette indre skel blandt Marazig-befolkningen vil denne dog altid føle sig som en samlet enhed med indbyrdes loyalitet $\mathrm{i}$ forhold til Aouina-befolkningen.

\section{Identitet og magt}

Den identitetsmæssige virkelighed, der gør sig gældende i befolkningen, og som her er eksemplificeret $i$ byen Douz, viser et helt andet billede med mange flere detaljer og inddelinger end det, som styrets offici- elle nationale identitet giver indtryk af. Eksemplet viser også, at identitet som knytter sig til stamme og familie, ikke blot er noget, befolkningen føler, men at det i høj grad er regulerende for den enkelte i hverdagen.

Magt i såvel erhverv som offentlig administration i lokale sammenhænge er stærkt præget af de uformelle magtstrukturer og opfattelser af hvem der er 'de rigtige' og dermed legitime i magt-sammenhænge.

$\varnothing$ konomisk er den enkelte helt afhængig af fællesskabet i familien eller stammen, idet Tunesien ikke har et socialt sikkerhedsnet, der sikrer den enkelte i alderdommen og ved sygdom og arbejdsløshed. Her træder familien og stammen ind i stedet for.

På det sociale plan spiller stammen og familie en rolle for, hvem man taler med, besøger og omgås. I yderste konsekvens betyder det ikke kun, hvem man drikker kaffe med, men også, at unge fx ikke gives tilladelse til at deltage i kurser og projekter, der ledes af familier, som man ikke omgås eller har bånd til. Familien og stammen giver således muligheder og sætter begrænsninger.

I en vurdering af og forståelse for demokratiprocessens status quo i Tunesien får familiens og stammens aktualitet en række konsekvenser. De klare opfattelser i lokale sammenhænge af 'dem' og 'os' og af, hvem man har alliancer med, og hvem man er imod, knytter sig ikke til politiske partier, faglige organisa- 
tioner eller civilsamfundsgrupper, men alene til familien og stammen.

Alle disse forhold betyder tilsammen, at individet, som er en absolut forudsætning for og grundpille i demokratiet, ikke gives betingelser for at eksistere og udfolde sig. Det enkelte menige familiemedlem er ikke vant til at deltage i beslutningsprocesser, til at tænke sig ind i civilsamfundsorganisationer eller politiske tilhørsforhold.

Det forhold at man ikke kommer i visse dele af byen alene med den begrundelse, at her bor de andre, og at man betragter folk fra disse kvarterer for ikke at tale om folk fra andre byer som fremmede, tydeliggør, at den homogenitet som ofte er udgangspunktet for Tunesien, ikke er præmissen set fra den tunesiske befolknings side af bordet. Her dominerer diversitet og skel, som der endnu ikke har været mulighed for at tænke ind i nationalstaten, i civilsamfundets struktur og i den politiske organisering.

\section{Landelitens sejr}

Bevæger man sig opad fra det lokale niveau, hvor den enkeltes forhold reguleres inden for rammerne af familien og stammen, viser det sig, at et netværk af alliancer også gør sig gældende blandt den erhvervsmæssige og økonomiske elite i Tunesien.

Trods Tunesiens proklamerede socialistiske ideologiske linje med staten som det eneste officielle lokomotiv, viser det sig i kølvandet på de økonomiske reformer, at der er vedblevet at eksistere en elite på landet $\mathrm{i}$ hele Tunesien under såvel Bourguiba som Ben Ali, og at denne elite nu får karakter af patroner i forhold til de lokale småbønder.

De økonomiske reformer blev et krav blandt andet fra EU's side i forbindelse med Tunesiens associeringsaftale fra 1995. I aftalen blev det formuleret, at alle monopoler, statstilskud og særlige ordninger for offentlige virksomheder, der forhindrer den frie handel mellem markedets parter, skulle afskaffes. Midlet skulle være privatisering af de mange statsejede virksomheder, der var et levn fra Bourguibas socialistisk prægede ideologi.

Som følge heraf blev der i perioden fra 1986 til 1990 solgt 33 statsejede virksomheder, mens 60 virksomheder, heriblandt 20 hoteller, i perioden 1990 til 1993 overgik til private ejere. De statsejede landbrugskooperativer er også blandt de tidlige statsejede virksomheder, der privatiseres.

Salget af landbrugsjorden spiller en central rolle i forståelsen af, hvad der reelt er sket med liberaliseringen af den tunesiske økonomi. Da kooperativernes jord blev solgt, var det de bønder, der ejede mindst 100 tønder land i forvejen, der fik muligheden for på særligt gunstige vilkår at tilegne sig den tidligere statsejede jord. Det umiddelbare argument herfor var, at kun store landbrug ville være økonomisk stærke 
nok til at klare sig i konkurrencen med udenlandske investeringer i landet samt i den internationale konkurrence.

Andre forhold har imidlertid også gjort sig gældende. Styrets afhængighed af loyalitet og støtte fra den landbaserede elite er ét vigtigt forhold. Siden 1969, hvor planer om storstilet nationalisering af landbruget mødte så markant modstand fra de store herremænd, at det skabte ustabilitet for styret, har der eksisteret et tag-og-giv forhold mellem landeliten og styret.

Landeliten yder styret støtte og sikrer det loyalitet blandt den lokale befolkning, mens styret har sørget for at tilgodese landeliten og tildelt den forskellige goder. Privatiseringen af de tidligere statsejede landbrugskooperativer er et af de nyligste eksempler på en sådan tilgodeseelse og styrkelse af landeliten og en sikring af dennes loyalitet over for styret.

Således har der gennem tiden eksisteret en tæt, men yderst uformel kontakt mellem denne landbaseret elite og landets ledere og regeringspartiet.

\section{Småbøndernes nederlag}

Mens landeliten således er blevet vinderne i privatiseringen af landbrugskooperativerne, idet de har brugt deres nære kontakt til styret til at erhverve mere jord, er taberne ved privatiseringerne på landet blevet småbønderne. I kooperativ-peri- oden var det kun tilladt for disse bønder at eje 5-10 tønder land. Med afgrænsningen af opkøbere til de bønder, der i forvejen havde 100 tønder land, blev det uden for småbøndernes rækkevidde at erhverve sig mere jord.

Ydermere har privatiseringen af kooperativerne betydet, at småbønder er endt i et afhængighedsforhold til de store herremænd. I tiden med kooperativer havde bønderne mulighed for at låne kooperativets landbrugsmaskiner til en mere intensiv dyrkning af egen jord. Efter kooperativernes opløsning og privatisering blev også maskinerne de store herremænds eje, og disse har ingen interesse i at skabe konkurrenter for sig selv ved at hjælpe småbønderne til effektivisering af deres dyrkning af jord. Som konsekvens er der ikke længere traktorer og moderne redskaber til rådighed for småbønderne. Endelig er mange arbejdere, der tidligere havde været ansat i kooperativerne, blevet helt eller delvist arbejdsløse i de privatiserede storbrug, idet de store herremænd søger at mindske deres driftsomkostninger gennem fyringer $\mathrm{og}$ brug af sæsonarbejdere.

Småbønderne har således ikke haft midlerne til at klare sig i den nye markedsorienterede $\varnothing$ konomi, og hvor de tidligere var sikret økonomisk i kooperativerne, er de nu blevet afhængige af de lokale herremænd. Det er nu dem, der kan sikre arbejde og yde økonomisk hjælp i 
form af lån og almisser. Dette forhold har slående ligheder med det traditionelle patron-klient forhold, og det gør, at strukturen på landet i Tunesien efter reformerne og som en direkte konsekvens af disse kan betegnes som et neo-patron-klient forhold.

I et demokratiserings-perspektiv betyder neo-patron-klient forholdet og landelitens nære forhold til centralmagten, at man har bevæget sig væk fra udviklingen mod demokrati og pluralisme snarere end, at man er nået et skridt nærmere til målet.

Småbønderne er først og fremmest optaget af at sikre deres egen overlevelse og beskæftigelse. Reformerne har derfor ikke skabt en ny landbaseret gruppe af entrepren $\varnothing$ rer, som har en egeninteresse i at kræve meddeltagelse i og indflydelse på de politiske beslutninger. Tværtimod har deres afhængighed af herremændene betydet, at de har al mulig interesse $\mathrm{i}$ at lefle for herremændene og vise deres loyalitet over for disse.

Herremændene har på deres side brug for denne loyalitet fra bønderne, fordi det giver dem magt bag de krav, de fremsætter over for centralmagten. Bønderne er blevet herremændenes klemme på magthaverne. Den landbaserede elite er således langt fra blevet svækket af de $\varnothing$ konomiske reformer, og det er ikke blandt småbønderne, at man skal kigge efter nye aktører på den tunesiske politiske scene.

\section{Snæver elite med politisk magt}

Ikke kun på landet, men også i industrien og den private del af servicesektoren er det vanskeligt, måske endog umuligt, for små iværksættere at få fodfæste i den nye liberale økonomi. Men også veletablerede handelsfolk beretter om forfordeling og vanskelige vilkår i den daglige drift af deres virksomheder.

\section{Årsagen hertil skal findes i den} struktur, der knytter sig til den reelle magtstruktur i Tunesien. For selvom landeliten spiller en væsentlig rolle som garanter for lokal sikring af styrets magt, så ligger den reelle politiske magt hos en snæver elite, der er tæt knyttet til præsidenten.

Kun gennem en position inden for eller kontakt til det hierarki, som gør sig gældende i denne politiske elite, er det muligt at opnå politisk indflydelse og blive afgørende tilgodeset i erhvervsmæssige henseender. Det hierarki, som den politiske elite er bygget op omkring, er ikke et top-down hierarki men betegnes bedre som bestående af tre cirkler uden på hinanden.

I den yderste cirkel er ledere på mellemniveau inden for organisationer, fagforeninger og interesseforbund. Deres primære opgave er at udføre beslutninger taget i de inderste elitecirkler. De har ingen mulighed for at protestere mod beslutningerne og har ingen mulighed for at opnå magt, men har gennem deres position nogen mulighed for indflydelse. 
I midten af magthierarkiet befinder den udøvende elite sig. Det er statsbureaukrater, regeringspartiet og øverste ledere fra organisationer og erhvervslivet. Denne del af eliten har en betydelig indflydelse på den førte politik og opretholdelse af magt, men har ingen indflydelse på de strategiske anliggender. Dette er udelukkende forbeholdt den øverste elite, som udgøres af en lille snæver kreds omkring præsidenten. Én del af denne lille elite udnævnes og udvælges af Ben Ali selv. Det drejer sig om ministrene for magtministerierne, dvs. inden- og udenrigsministeriet og ministerierne for sociale, økonomiske og internationale anliggender. Den anden del af eliten udgøres af personer, der er i familie med eller har nære, personlige forbindelser til Ben Ali og hans kone Laila Trabelsi. Personerne fordeler sig på fem klaner: Brødre og søstre til Ben Ali, til Laila Trabelsi og de tre familier Chiboubs, Mabrouk og Zarrouk, der gennem ægteskab med Ben Alis døtre har fået en direkte relation til præsidenten.

\section{Personlige bånd til præsidenten}

Ved privatiseringerne af de tidligere statsejede industrier og virksomheder er det primært personer fra selve den politiske elite eller med de tætte bånd til den, der først er blevet orienteret om salget af de pågældende virksomheder, og som dermed har haft muligheden for at erhverve dem. Det industri-bourgeoisi, der er blevet skabt i kølvandet på privatiseringerne, udgøres således af den snævre politiske elite, som i en eller anden udstrækning har familiære eller personlige bånd til præsidenten.

Tunesien har to handelsorganisationer, som kunne forventes at være med til at fremme salget til en bredere skare af entreprenører og dermed igangsætte udviklingen mod pluralisme, men som viser sig som partiske og dybt involveret i hele magtkoncentrationen af den private sektor. Den ene, Union Tunisien de l'Industrie, du Commerce et de l'Artisanat (UTICA) ledes af Hedi Djilani, svigerfaren til Laila Trabelsis ældste bror, mens den anden handelsorganisation, Institut Arabe des Chefs d'Entreprise (IACE) ledes af Chakib Nouira, søn af Hedi Nouira, der blev den nye premierminister efter landelitens oprør mod nationaliseringerne i 1969.

Chakib Nouira er endvidere øverste leder for Tunesiens største private bank, Banque Internationale Arabe de Tunisie (BIAT). Præsidentens niece Dina Ben Ali har siden 2002 været den nye ejer af en række store vingårde, der tidligere var statsdrevne, hvilket blot er ét eksempel på, hvordan salget af virksomheder primært sker inden for den elite, der knytter sig til præsidenten selv.

Ud over det moralske aspekt af, at salget af statens virksomheder går til præsidentens egen familie og nære bekendte, har dette udfald en afgø- 
rende betydning dels for, hvordan demokratiprocessen kan udvikle sig i de kommende år og dels for de muligheder, udefrakommende aktører som EU og Verdensbanken har for at agere og stille krav for at opnå mere demokrati og pluralisme.

Siden Ben Alis tiltrædelse som præsident i 1987 er magten blevet stadig mere koncentreret omkring ham og regeringspartiet. Ved sidste præsidentvalg i 2004 fik han ændret grundloven, så han kunne stille op for fjerde gang.

Men magten er ikke kun sikret rent politisk. Gennem salget af de statsejede virksomheder til præsidentfamilien sikrer Ben Ali sig også den økonomiske magt. Og ikke alene har han sikret sig magten her og nu, men gennem salget af statsvirksomhederne også, at hans familie fortsat vil have væsentlig indflydelse den dag, han selv enten på grund af alderdom eller et regimeskifte ikke længere kan bestride præsidentembedet.

Salget af statsvirksomhederne betyder endvidere, at Ben Ali viser sig som den reformvillige præsident, der træder i karakter som det gode forbillede til efterfølgelse af alle andre arabiske nationer og som den præsident, der villigt indgår i partnerskaber på de betingelser, som EU og Verdensbanken nu måtte opstille.
Derfor bliver det en udfordring for EU og andre internationale organisationer fremover at stille krav til Tunesien om noget-for-noget i bestræbelserne på at åbne vejen mod mere demokrati. For Ben Ali har indtil videre gjort som han er blevet bedt om, han har hævet statsmonopolet og privatiseret. Og det ligger ikke lige i kortene, at EU efterfølgende kan sige at ja, men det var ikke de personer, vi mente, der skulle sælges til.

Og hvem er de personer. For en ting er opkøbere som Dina Ben Ali, der har direkte familiebånd. Det er straks et helt andet arbejde at spore og kortlægge for ikke at tale om at sætte grænser for familiebånd og nære bekendtskaber, som dem der karakteriserer handelsorganisationernes ledelse.

Så langt i forløbet af de økonomiske reformer i Tunesien må det konstateres, at der nok er sket forandringer i ejerforhold, men at den tilsigtede forandring i de politiske magtstrukturer og politisk indflydelse ikke er sket.

Der er snarere sket det modsatte, en konsolidering og styrkelse af den siddende magtelite.

Rikke Hostrup Haugbølle er amanuensis på Center for Mellemøststudier, Syddansk Universitet 